\title{
ACRONYMS AND TERMS
}

ANAMPOS Associação Nacional de Movimentos Populares e Sindicatos, or National Association of Popular Movements and Trade Unions

ANC African National Congress

CDF Community Development Forums

CEB Comunidades Eclesiais de Base, or Ecclesiastic Base Communities

CSO Civil Society Organization

CUT Central Única dos Trabalhadores, or Central Workers Union (CUT)

FAMOCA Federation of Neighborhood Associations of Camaragibe

IBGE Instituto Brasileiro de Geografia e Estatística, or Brazilian Institute of Geography and Statistics

ICMS Imposto sobre Circulação de Mercadorias e Serviços, or Tax on the Circulation of Merchandise and Services

IDP Integrated Development Plan

IPTU Imposto Predial e Territorial Urbano, or Tax on Buildings and Urban Lands

ISSQN Imposto sobre Serviços de Qualquer Natureza, or Services Tax

KSSP Kerala Sastra Sahitya Parishad, or Kerala's peoples science movement

MSC Movimento dos Sem Casa

PA Participatory Administration

PB Participatory Budget

PC do B Partido Comunista do Brasil, or Communist Party of Brazil

PCB Partido Comunista Brasileiro, or Brazilian Communist Party

PDS Partido Democrático Social, or Democratic Social Party (the PDS became the PPR in 1993)

PDT Partido Democrático Trabalhista, or Democratic Labor Party

PFL Partido da Frente Liberal, or Liberal Front Party 
PI Plano de Investimento, or Yearly Investment Plan

PMDB Partido do Movimento Democrático Brasileiro, or Brazilian Democratic Movement Party

Prefeito/Prefeitura the mayor, and city hall

PSB Partido Socialista Brasileiro, or Brazilian Socialist Party

PT Partido dos Trabalhadores, or Workers' Party

PTB Partido Trabalhista Brasileiro, or Brazilian Labor Party

RDP Reconstruction and Development Program

SABS the sociedades de amigos de bairro, or Societies of Friends of the Neighborhood

SANCO South African National Civics Organisation

STMJM Sindicato de Trabalhadores Metalúrgicos de João Monlevade, or Metalworkers' Union of João Monlevade

Vereador(a) a member of the municipal legislature, equivalent to a city councilor in the United States 
Bootstrapping Democracy 
